\title{
Ellipsis
}

\section{The Moral Responsibility of Readership: An Examination}

\author{
Maya Lowy \\ University of New Orleans
}

Follow this and additional works at: https://scholarworks.uno.edu/ellipsis

\section{Recommended Citation}

Lowy, Maya (2015) "The Moral Responsibility of Readership: An Examination," Ellipsis: Vol. 42 , Article 5. DOI: https://doi.org/10.46428/ejail.42.05

Available at: https://scholarworks.uno.edu/ellipsis/vol42/iss1/5

This Essay is brought to you for free and open access by the Department of English and Foreign Languages at ScholarWorks@UNO. It has been accepted for inclusion in Ellipsis by an authorized editor of ScholarWorks@UNO. For more information, please contact scholarworks@uno.edu. 


\title{
The Moral Responsibility of Readership: An Examination
} Maya Lowy

The Malcolm Magaw Prize

Artists [...] are bound by a much sterner law than that of social morality and it is the insistence of its demand that is the source of both the agony and the glory of their calling.

\author{
-Arnold Berleant \\ “' What does it matter who is speaking,' someone said, 'what does it matter who is \\ speaking.",
}

—Michel Foucault, quoting Samuel Beckett

For a long time, the art of literature was morally divorced from the conception of authorship. Oral poetry focuses more on doing the story justice than on innovation; and even with the development of a written system, for centuries the writer was viewed as more of a vessel for the Muses to work through than a bona fide author. According to Foucault, the shift toward authorship begins "in the seventeenth or eighteenth century [... when] literary discourses came to be accepted only when endowed with the author function" (551). Yet even in more modern times, to a critics like T.S. Eliot, "the progress of an artist" is defined as "a continual extinction of personality" (28). The text exists on some other plane, to be drawn forth from the ether; the author is little more than a medium.

"A poem should not mean / But be," Archibald MacLeish asserts in his 1926 "Ars Poetica." But of course poems "mean" all the time, poets "mean" all the time, and this type of apolitical, apersonal ideology can only take us, as readers, so far. All authors have moralities, some which differ strongly from those of their readers; by reading somebody whose morals we disagree with, are we implicitly supporting those morals? What if we agree with them on some questions, but not on others? Is engaging with different mentalities ultimately useful in clarifying our own positionality? And what if the authors' time, their context, is so different from our own that it seems unfair to measure them on our terms?

In contextualizing a work, in trying to fully understand it, most of today's critics agree that we must study its creator. Even Eliot admits that "the great poet, in writing himself, writes his time" (38). Just as we need to recognize Shakespeare's temporal and spatial surroundings in order to deeply understand his work-just as Wordsworth's poem 
"London, 1802" makes little sense outside a Romantic context, and without an awareness of who John Milton was in relation to Wordsworth-so, it can be argued, we must also look at the life of the author on a more personal scale. William Carlos Williams, for example, was a doctor and often wrote his small poems on the backs of prescriptions. Elizabeth Bishop whimsically jumped on a boat to Brazil, had an allergic reaction to a nut and wound up living in Petrópolis for fifteen years. Is this information integral to our comprehension of the text? Perhaps; it is, probably, integral to our full comprehension of the $a r t$.

In her introduction to a primer for reader-response criticism, Jane P. Tompkins credits Georges Poulet with the definition: "to read is precisely not to be aware of the structural and stylistic properties of the work but to be immersed in the author's mode of experiencing the world" (xiv). In the same vein, Stanley Fish asks, "If a reader does not share the central concerns of a work, will he be capable of fully responding to it?" (88) Although the reader is the focal point of this school of criticism, the author and the author's context cannot be denied.

More politically, in today's tiptoeing literary climate, it is unthinkable to read a text without taking into account the race, gender, class, and general background of the author. Today's readers are hyperaware of the patriarchy, of postcolonialism, of different layers and boxes of oppression. One recent headline on CNN.com, "Kids author: sorry for 'racist' joke," exemplifies this. The article states that this year's National Book Awards host, Daniel Handler (novelist and children's author), co-opted black American author Jacqueline Woodson's memoir's win with an offensive joke about Woodson's watermelon allergy. "Some prominent writers," including Roxane Gay, Laila Lalami, and Mikki Kendall, "quickly took to Twitter to denounce Handler's comments as racist," CNN reports; "Handler responded with several apologetic tweets" and wound up penitently donating $\$ 110,000$ to a campaign entitled "We Need Diverse Books."

This controversy sets the scene for the type of critical environment we operate within today. In a culture where social media sites skyrocket above regular-media sites in daily clicks, where most young people's awareness of current events comes from Facebook, Twitter and Buzzfeed, where the concept of "clickbait" trumps any objective attempt at classifying the importance of a story-we are all each other's curators of the news. This means that popularity bestowed upon a story gets it more exposure than anything else could; a scandal can easily "go viral." And the moral judgments of certain influential people-people who can assert what they think with confidence, people with internet clout—carry more weight.

At the same time, it is a mob judgment. Racism is bad. Anti-Semitism is bad. Sexism is bad. Sexual assault is bad. Child molestation is bad. Disrespect is bad. Fascism is bad. Murder is bad. People who practice these things, and people who hold different views about them, are bad people; they deserve to be punished, or at the very least to be publicly shamed. When these bad people are already famous, it is particularly important to "out" them, because their increased social status and social power allow them not only to continue doing bad things, but to have their bad actions be excused. It is wrong to allow a bad person more influence, more clout, than he or she deserves.

These are the mores of the culture we live in-and they are by no means inherently problematic morals (at least, not to this critic, who operates within their 
parameters). In fact, in many ways they serve to correct parts of our society which are problematic. They recognize that we are not in a post-racist, post-sexist, post-badness world: if somebody is going to be victimized, maligned, hated, better that it be the bully, the person who victimized others. (This ideology is expressed not only on the artistic scale, but very much on the political as well: for example, the ongoing riots in reaction to the unprovoked shooting of a black boy in the Ferguson neighborhood of St. Louis, Missouri, speak to the unacceptability of unchecked police brutality and racial privileging in the justice system.)

Once a work of art is published, it exposes itself to criticism, dialogue, and judgment. "Such is the paradoxical situation of the artistic vocation," according to critic Séan Burke in his 2008 study The Ethics of Writing: "culture demands an elect to which it grants imaginative freedom, but only at the price of accountability" (19). And with accountability comes consumer responsibility. A blogger by the name of "Eldritch" responds to the Daniel Handler scandal with an essay which serves as a crystalline example of this question plaguing the modern reader-as-consumer, this moral responsibility of the reader. Eldritch outright declares a boycott on Handler's work: "It's my personal policy to not support authors/artists/entertainers/etc. who show themselves to be racist, anti-feminist or homophobic. I don't want to support (with money or otherwise) people who have views that are so repugnant." She then follows up with a question that obviously plagues her: "So why do I still say I'm a fan of H.P. Lovecraft?"

In this capitalist and pseudo-democratic world, the concept of "voting with your dollar" is so ingrained in us that consumers of art ask themselves what should I be reading? in the same way that they ask themselves what should I shop for? In many ways, the question of artistic consumerism overlaps with conscientious consumerism in other realms: thoughtful readers can be conceptualized as analogous to, and often overlapping with, people who buy groceries from the farmer's market and choose "ecofriendly" oil at the auto center. Yet ideas are a little different than purchases, and art is a little different than morality. Philosopher Arnold Berleant, in his 1977 essay "Artists and Morality: Toward an Ethics of Art," asks us directly:

Do the moral constraints that prevail as part of the social code apply equally to [artists], or is their activity so distinctive that it requires them to occupy a privileged place, uniquely immune to the rules [...?] Does the influence of artists on their society justify social concern and control over their activity? Do artists' contribution to the life of the community justify their being subsidized or supported by society and, if it does, what rights does society acquire as their patron? (196)

One could counter with a non-author-centric theoretical standpoint, where the moral question of "support" loses most of its relevance. In "The Death of the Author," Roland Barthes writes that "the Author, when believed in, is always conceived of as the past of his own book [...] in the same relation of antecedence to his work as a father to his child" (145). Barthes refutes this concept in favor of what he refers to as "the modern scriptor," who is "born simultaneously with the text" and therefore allows the reader to look at the work with less limitations (145). Burke summarizes this type of viewpoint as believing 
that "the literary work is independent of its creator and answerable only to itself" (20). But he then debunks the ideology, reminding us how reality works:

In a world of textual anonymity, the author would be protected from the effects of the text and the text protected from the effects of its author's life. Authors would not have been persecuted or denied expression by oppressive regimes; female authors would not have felt impelled to adopt male pseudonyms in order to gain a respectful audience. (20, emphasis added)

Separating the author and text is effectively impossible-in part because authors are held accountable in different ways depending on who they are, and in part because they truly do put themselves into the work, especially when they are writing about something they truly care about (as most writers do).

One rather heinous but effective example is that of Ezra Pound. Alireza Farahbakhsh tells us that "throughout The Fifth Decad of Cantos [...] Pound's economic and political ideologies are [...] closely intertwined" (Farahbakhsh 3), and his economic frustrations (Canto XLV, for instance, is all about "usura") were "the very root of Pound's deep hatred of the Jews" and the "virulent anti-Semitism" in his language (4). Pound, a contemporary, friend, and mentor of T.S. Eliot's, single-handedly disproves Eliot's claim that the artist is no more than a medium, an extinct personality. His poetry is brimming with his personality, his ideologies, his convictions-convictions which are, through today's lens, universally acknowledged to be not only wrong but bad. Pound is not merely writing as a vessel-he is trying to convince his reader of his views. Honestly, much of the Cantos read less like poetry and more like a crazed rant:

Profit on arms sold to the government: Morgan

(Case 97) sold to the government the governments' arms...

I mean the government owned 'em already

at an extortionate profit

Dollars 160 thousand, one swat, to Mr Morgan

for forcing up gold. (Pound, "Canto XL")

In typical Modernist fashion, Pound throws allusions at us without really caring which ones we can actually follow. But he seems to still want us to agree with him. The result, for the reader, is not dissimilar to listening to a senile extremist: he does a lot of yelling that makes little sense and is mostly uncomfortable.

Interestingly, though, in his prose as well as some of his less overtly political poetry, Pound can be incredibly lucid, pristine in his language*. One cannot just write off Pound as a crazy, anti-Semitic fascist; although his views on many topics were, we can now agree, wrong, he was in other ways incredibly enlightened. The function of literature, he wrote, "is not the coercing or emotionally persuading, or bullying or

\footnotetext{
"Ezra Pound, "How to Read," pg. 22: "It is as important for the purpose of thought to keep
} language efficient as it is in surgery to keep tetanus bacilli out of one's bandages." 
suppressing people into the acceptance of any one set or any six sets of opinions" (21). And as proof of this fact, most of Ezra Pound's fans are not fascists or anti-Semites. Readers are capable of enjoying somebody's work without being brainwashed by it, and it is demeaning to assume otherwise. On the other hand, "Morals are open to being altered by literature," wrote T.S. Eliot,

so that we find in practice that what is "objectionable" in literature is merely what the present generation is not used to. It is a commonplace that what shocks one generation is accepted quite calmly by the next. This adaptability to change of moral standards [...] is only evidence of what unsubstantial foundations people's moral judgements have. (145)

Is it possible, then, that exposing ourselves to the art of a bad person, like radiation, will warp our minds? Was this the argument behind the McCarthyist blacklisting of Communist-sympathetic artists during the Cold War? Surely, this is the argument behind censorship and book-burning, behind Fascist suppression of art. Censorship, we can also agree, is bad. At least when the bad guys do it.

Ironically enough, it is Ezra Pound himself who supplies us with the beginnings of a solution to this moral quandary. He suggests that "we apply a loose-leaf system to book-keeping, so as to have the live items separated from the dead ones" (18). This is the conclusion Eldritch, the morally divided blogger, comes to as well: "Boycotting a living author is like boycotting a store," she says, while Lovecraft, who she describes as "virulently racist, anti-Semitic and elitist," cannot send out "apologetic Twitter messages"- and also is not being financially supported by his modern-day readers. As a compromise, she suggests that Lovecraft's books "have a disclaimer before them [...] saying that his writing is a product of his time and his intolerance is abhorrent today but was not viewed as harshly back then." Authors should be placed within their own contexts-so post-poststructuralist thought goes, anyway-and a writer who is no longer alive, and cannot profit from our purchases or turn our respect into a destructive force, can be enjoyed with less trepidation than a writer whose fame can be turned into an oppressive tool.

But what about when the good guys are the ones pulling work from the shelves, and it's current work, where supporting the author is a real question? Gregory Sherl is a contemporary white male poet getting his MFA at the University of Mississippi; he's part of the movement called "alt lit" which has been active in the past fifteen years or so, and which has recently been the center of a major controversy, in large part thanks to Sherl himself. As online reviewer Zachary Herle summarizes it, Sherl's attempt to crowd-fund his treatment for obsessive-compulsive disorder led to several of his ex-girlfriends, poets themselves, "coming forward claiming that the author emotionally, physically and, in at least one case, sexually abused them," with his victims' ultimate call to the public being that Sherl "doesn't require your money, pity or attention to his books." This last is the key element here. If Sherl is a bad guy, bad to his girlfriends and bad to the people he knows, then we probably shouldn't be giving him "money" or "pity" (although the mental illness lens can certainly complicate this debate). But "attention to his books"? 
Well, as it happens, Sherl's writing is often primarily about the women he has objectified and hurt. Here is an excerpt from his book of poems, Monogamy Songs, focusing on his toxic relationship with Kat Dixon (who claims she had to fight to keep her real name out of the text):

\section{[...] The spinning}

ceiling fan is a high-pitched whine only a dog

can hear. Soon, we will be married \& the dog will hear

the whine, will only care a little. In the dream, by

the time you think about leaving, it is so late the roads

are closed for the night. Your fake fit is a quintessential

sneeze. You left your keys on the windowsill.

You stay anyway.

(Sherl, "Let Me Leave Before the Medication Wears Off")

Clearly, taking into account the context and information that we have, this fits into a chilling portrait of an abusive relationship. So is support of Sherl's work, then, implicitly supporting Sherl's destructive actions? According to his victims, yes: Kat Dixon tweeted, "You have the man who beat and raped you write a book about you and then tell me we have to separate the artist from his 'art." When it is presented this way, we have to agree with her.

Yet this ideology runs along a slippery slope. When, for instance, can we make the assumption that the speaker and the artist are the same person-or close enough to the same that our moral judgment of one coincides with the other? The dramatic monologue practiced so determinedly by poets like Ai and Robert Browning, as a contrast, exonerates its reader of the moral question Dixon presents above. But poems which are less obvious, and by extension less safe, about this distancing run the risk of backfiring on their authors, and forcing their readers to question their own positionality.

Dixon was involved with Gregory Sherl before he was, comparatively, famous: he "was just starting to pick up publication steam. Now, he has a lot more power." One can extrapolate that such a manipulator, without being publicly checked by those who disapprove of his actions, could be even more dangerous - that our responsibility, then, is to stifle his voice. (Never mind that the poem speaks for itself; the public accessibility of examples of Sherl's offensive poetry is undeniably useful in a project like this one.) Gregory Sherl, as a human being and contemporary of his moral judges, is not cut the slack that authors like Lovecraft, Eliot, or Pound might get away with—knowing that he lives in our time, that he is educated, that he is American, implies that he has been exposed to the type of theory that damns his personal choices. Sherl is undeniably aware of the scandal his "crazy ex-girlfriends" have propagated; still, he has refused to make any comment. Berleant reminds us that "the morality of the artist is before all else, the morality of a person" (197). Faced with evidence of Sherl's crimes against women, we must hold him accountable as a person, and in this case that also means holding him accountable as an artist.

Holding Sherl accountable is not the same thing as unpublishing him, though. And in the wake of the feminist outrage, several small presses have done just that, 
"publicly cutting their ties with him and standing in solidarity with the women who had spoken up," according to Sarah Certa, another ex-girlfriend, writing for the Daily Dot in an article by Miles Klee. Certa alleges that "this is what we need to see on a larger scale." So is the battle here about censorship versus "solidarity," censorship versus support? From the point of view of the presses, it may be a political action to publish a poet like Sherl; it is a far more political action to unpublish him, which is probably why Sherl's larger-profile backers like Oprah's book club have hesitated to take action. This is troublesome to Sherl's detractors because by continuing to endorse his work, these publications are implicitly allowing Sherl to remain in the powerful position Dixon and Certa allege that he is in. Even Eliot argued that "what is more insidious than any censorship, is the steady influence which operates silently in any mass society organized for profit, for the depression of standards of art and culture" (143). The operative word here, of course, is insidious, with its implications of treachery and danger. Is it irresponsible to publish something that is dangerous - even if it will sell-even if it, maybe, is good art?

For on a larger scale, isn't most good art almost inherently dangerous? Berleant describes a "morality of creativity," where artists make decisions that clash with their society's mores (Rimbaud leaps to mind, as does Poe, as does Lord Byron, as do the Beats): "A principle of aesthetic priority seems to be at work, in which the integrity of the artist takes precedence over the comfort of the community" (199). Art would not be art without taking risks, without pushing boundaries, without challenging comfort levels, without making critics and theorists sweat. Attempts to classify art have always failed, because art by nature is challenging. That is the whole beauty of it-it keeps us on our toes, it keeps us off-balance.

And it seems dangerous in the wrong ways to censor people whose morals do not align with those of the majority (even if that is, sometimes, just a euphemistic way to say "bad people"). It seems pejorative to withdraw certain authors from the public eye because their views are wrong; it seems authoritarian and undemocratic. "In the act of publication," Burke tells us, "the writer, like any ethical agent, implicitly signs a contract with society, and accepts the possibility that a tribunal may one day assemble around the work" (21). Judgment is fine-censorship is not. Silencing is not.

Emboldened by exposés like Gregory Sherl's, women across art forms have recently come out with sexual-assault accusations against publicly beloved artists like Bill Cosby and Woody Allen. By no means should we unpublish them, or stifle their artistic voices. But let's take into account what we know about these authors when we analyze their past work, the same way we do with Ezra Pound and Daniel Handler-and let's make them feel accountable for their actions, just as they signed up for when they accepted a life of celebrity. When we do not know much about an author's personal life, we should not leap to conclusions based on their race, gender, class, or general background-or conclusions based on the text. But when scandalous information is presented to us, it is productive to acknowledge it.

It is possible to like somebody's work without approving of them as a person*. As Whitman said, "I contain multitudes;" bad people are not incapable of writing good

*Eliot, Points of View, pg. 15: "Fact cannot corrupt taste." 
poems; Berleant's morality of creativity and morality of humanity are different standards of measurement. Ultimately, the author, as a person, is responsible for his or her personal moral decisions; the reader is responsible for alert and contextualized engagement with the text. Censorship is wrong, and so is the practice of avoiding authors and works which are seen as problematic. But as Eliot has shown us, morals change, and this critic's morals are no different; let the tribunal assemble, and the dialogue continue. 


\section{Works Cited}

Barthes, Roland. "Death of the Author." Image, Music, Text. New York: Hill and Wang, 1977.

Berleant, Arnold. "Artists and Morality: Toward an Ethics of Art." Leonardo 10.3, 1977: 195-202. MIT Press. JSTOR.

Burke, Séan. The Ethics of Writing. Edinburgh: Edinburgh UP, 2008.

Dixon, Kat. (@katlaine) "You have the man who beat and raped you write a book about you and then tell me we have to separate the artist from his "art."” Twitter, 16 Nov. 2014. Web.

Eldritch. "My Complicated Relationship With H.P. Lovecraft." Observation Deck, 20 Nov. 2014. Web.

Eliot, Thomas Stearns. Points of View. London: Faber and Faber, 1941.

Farahbakhsh, Alireza. "The Anti-Modernist Quality of Ezra Pound's The Fifth Decad of Cantos (Cantos XLII-LI)." War, Literature and the Arts: An International Journal of the Humanities 24, 2012. Web.

Foucault, Michel. "What is an Author?" Criticism: Major Statements, ed. Charles Kaplan and W.D. Anderson. Boston/New York: Bedford/St. Martin's, 2000 .

Houle, Zachary. "Love is a Sad Thing in 'The Future for Curious People."” PopMatters, 15 Nov. 2014. Web.

Klee, Miles, and Sarah Certa. "Inside the campaign against Gregory Sherl, poet and alleged abuser." The Daily Dot, 13 Nov. 2014. Web.

Locke, Frances. "On the Abuse and Sexual Assault Allegations Against Oprah's Book Club Author Gregory Sherl.” The Frisky, 14 Nov. 2014. Web.

MacLeish, Archibald. “Ars Poetica.” 
McAfee, Melonyce. "'Lemony Snicket' author sorry for 'racist' joke at National Book Awards." CNN, 21 Nov. 2014. Web.

Pound, Ezra. "How to Read." Literary Essays of Ezra Pound. New York: New Directions, 1968.

---. "Canto XL."

Sherl, Gregory. "Let Me Leave Before the Medication Wears Off." Four Poems, PANK Magazine, 6.05, May 2011. Web.

Tompkins, Jane P., George Poulet, and Stanley Fish. Reader-Response Criticism: from Formalism to Post-Structuralism. Baltimore: Johns Hopkins UP, 1980. 